\title{
Critical Analysis of the Definition of the Meter
}

\author{
Patrice F Dassonville* \\ Department of physics and chemistry, University of National High School of Niamey, France
}

Received: January 11, 2018; Published: January 17, 2018

*Corresponding author: Patrice F Dassonville, Department of physics and chemistry, University of National High School of Niamey, France

\author{
Abstract \\ Defining the meter is an inavoidable step towards identifying the nature and properties of physical space. It turns out that the international \\ definition of the meter raises some questionings, partly because of the vagueness and the inconsistency of the wordings.
}

\section{Introduction}

\section{The Concept of Length}

Given that length is a concept, we do not measure the length of an object, but we measure what separates its ends: the result of the measurement is called « length of the object».

The Greek mathematician and geographer Eratosthenes (276-194) succeeded in evaluating the Earth circumference, by comparing the drop shadow of the same object in two different places. Strictly speaking, Eratosthenes did not measure the length of the shadows; instead he measured what separates their ends. The result of each measurement is called « length of the shadow ».

In addition, the length of an object is a concept without physical existence as such.

\section{Origin of the meter}

The definition of the length unit is the object of an impressive diachrony, as it is testified in the Manuel des Poids et Mesures published by A. Tarbé in 1840 :

The uniformity of weight and measurements was wished since a long time. This whish of Charlemagne, Philippe-le-Long (1321), Louis XI, François I (1540), Henri II (1557), Henri III (1575) and Louis XV (1766) had found insurmountable obstacles, owing to provincial prejudices and mainly local habits. However, there are only few abuses as much inconvenient as the diversity of measures, because it introduces uncertainty and mistrust...

The Académie des Sciences has been mandated by the constituent assembly (France, 1789-1791) for determining the weights and measurements units. The Academy used the quarter of the terrestrial meridian between the equator and the north pole for basis of the metric system [...] the length of the quarter of the meridian was approximately 5,132,430 toises; and the ten millionth part of this arc was almost exactly equal to 3 feet 11 lines 44/100.
The impatience to decide, pushed to decree that this would be the size of the provisional meter (Law of August First 1793).

The diachrony was not caused by time; instead, it was led by tenacious searchers.

\section{A First Definition of The Meter}

The law of 18 Germinal an III (April seventh 1795) stated:

Art. 2. There will have only one standard for Weights and Measurements for the enter Republic; it will be a platinum rule on which will be inscribed the meter, which has been adopted as the fundamental unit for the whole system of measurements [...] it will be registred at the legislature [...].

Art. 3. A model in accordance with the reference prototype will be sent in each district capital [...].

Art. 5. One will name: meter, the length measurement equal to the ten-millionth part of the meridian arc between the north pole and the equator Tarbé [1].

The Law of 19 frimaire an VIII (December tenth 1799) retained the final value of the meter at 3 feet 11 lines 296 thousandths Tarbé [1].

We can draft a first definition of the meter from these data:

«The meter is a concept which corresponds to the ten millionth part of the quarter of the meridian ».

\section{Proposal for a Speed Unit}

In 1983, the Conférence Générale des poids et Mesures decided:

«La vitesse de la lumière dans le vide « $\mathrm{c}$ » est égale à exactement 299.792.458 mètres par seconde ».

« The speed of light in the vacuum « $\mathrm{c}$ » is exactly 299,792,458 meters per second ». 
The speed of light « $\mathrm{c}$ » is a fundamental constant which is currently expressed in meter per second, « $\mathrm{m} / \mathrm{s} »$. We could replace " $\mathrm{m} / \mathrm{s}$ " by « cel », as international unit of celerity. Then the speed of light would read : c = 299,792,458 cel.

\section{Definition of the meter}

The same Conference of 1983 gave the meter a new definition:

« Le mètre est la longueur du trajet parcourue dans le vide par la lumière pendant une durée de 1/299.792.458e de seconde »

« The meter is the length travelled in the vacuum by the light during a duration of $1 / 299,792,458$ th of second ».

This definition is questionable for three reasons :

a) In 1983, the words «meter », « length», « duration » and « second» had no consistent scientific definitions.

b) Use the " meter » to define the " speed of light », then in the wake, use the "speed of light» to define the « meter »,is a truism.

\section{METER $=>$ SPEED OF LIGHT $=>$ METER}

c) More serious, the wording makes the meter dependant on the second ; with an obvious consequence : space is forced to depend on time. If we refer to our definitions of time and space, it's a nonsense:

«Time is a concept corresponding to what separates two states of a system ».

. «Space is a concept corresponding to what separates two systems »

According to these definitions, there is no relation between time and space.

In 2011, the Conférence Générale des Poids et Mesures declared:

« Le mètre, symbole m, est l'unité de longueur; son amplitude est déterminée en fixant la valeur numérique de la vitesse de la lumière dans le vide à exactement 299.792.458 lorsqu'elle est exprimée en unités SI m/s »

"The meter, symbol $\mathrm{m}$, is the length unit ; it's amplitude is determined by setting the numerical value of the speed of the light in the vacuum at exactly $299,792,458$ when it's expressed in m/s SI units ».
This definitions does not add any substantial information to the definition of 1983 ; Space is still depending on time.

The frequency of cesium is a constant of nature, « uneconstante de la nature » CGPM [2] ; hence, the " meter » can be defined compared to the wavelenth of cesium, which is not a fundamental constant :

$$
\lambda=\mathrm{c} / \mathrm{v}=(299,792,458 \mathrm{cel} /(9,192,631,770 \text { Hertz })
$$

«cel/Hertz » has the dimension of the international length unit, which is called meter : $1 \mathrm{~m} \# 0,032612256 \mathrm{~m}$.

Therefore, $\lambda \# 30,663319 \lambda$

« The meter is approximately equal to 30,663319 times the wavelength of cesium ».

\section{The metric system}

The law of July fourth 1837 made the metric system mandatory from January first 1840, in replacement of the traditional measures Tarbé [1]. Shortly before the end of World War II, an International Economic Conference was held between the 1st and the 10th of November 1944 in Rye in New York State: among various issues, it advocated the universal adoption of the metric system Céré [3] 6 th part.

It is remarkable that Anglo-Saxon countries and the countries of their former areas of influence are still not willing to comply with these provisions: the two systems are still used, with the risk of serious confusions.

In this connection, let's remind the decree of May 8th 1790 of the French National Assembly: [...] the King (Louis XVI) will be begged to write to her British Majesty, and ask her Majesty to convince the Parliament of England to contribute with the national assembly in fixing the natural unit for measurements and weights [...] Tarbé [1].

\section{References}

1. Tarbe M : Poids et mesures - (Librairie Encyclopédique Roret - Paris 1840).

2. CGPM : Conférence Générale des Poids et Mesures.

3. Céré R \& Rousseau Ch : Chronique du conflit mondial (1939-1945).
This work is licensed under Creative Commons Attribution 4.0 License

To Submit Your Article Click Here: Submit Article DOI: $10.32474 /$ PRJFGS.2018.01.000101

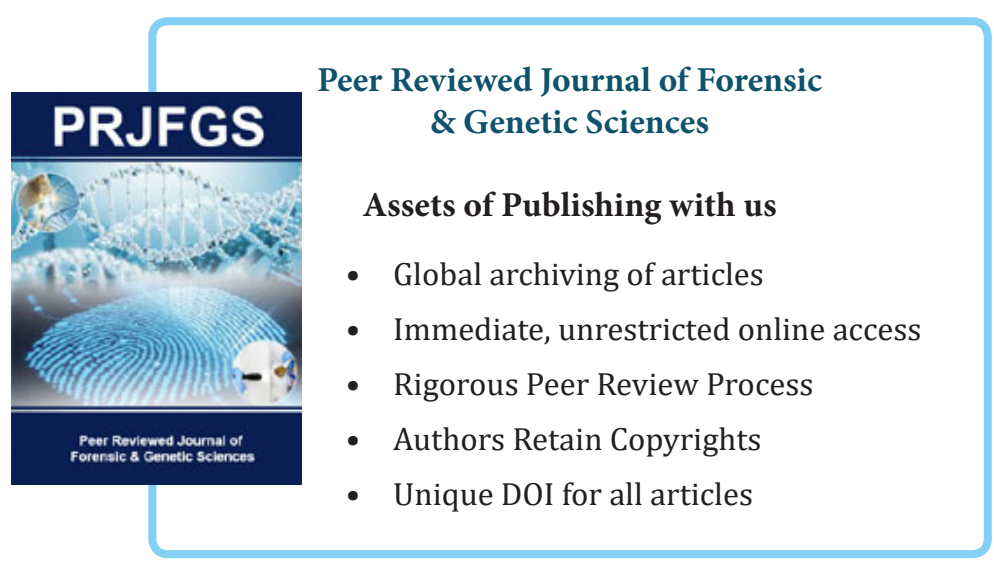

